\title{
Exploring the Determinants of MOOCs continuance intention
}

\author{
Donghyuk Jo \\ School of Business Administration, Soongsil University \\ Seoul, South Korea \\ [e-mail: joe@ssu.ac.kr] \\ *Corresponding author: Donghyuk Jo
}

Received February 27, 2018; revised May 29, 2018; accepted July 2, 2018;

published August 31, 2018

\begin{abstract}
In our current information-based society in which knowledge is a fundamental asset to production, the capability to utilize information and produce knowledge with the use of information technology (IT) has become essential to learning. Massive Open Online Courses (MOOCs) have recently been introduced in light of such changes and are recognized as an alternative to open education. MOOCs' capabilities are being acknowledged in lifelong education in terms of reeducation and knowledge sharing, and also in terms of improving teaching quality, and improving university students' levels of creativity and integrated thinking by supporting high-level content and teaching. Therefore, this study presents an extended research model that combines information system (IS) continuance and task-technology fit models. Our study researches previous literature, revealing factors of continuous use after accepting MOOCs from the learner's perspective, and analyzes the model empirically. The ideal environment for MOOCs learners is evaluated, and a strategic approach to the successful settlement and diffusion of MOOCs is presented based on this study's findings.
\end{abstract}

Keywords: Massive Open Online Courses (MOOCs), Task-Technology Fit, IS Continuance, Utilization, Perceived Usefulness, User Satisfaction

“A preliminary version of this paper was presented at ICONI 2017, and was selected as an outstanding paper.” 


\section{Introduction}

In our current, information-based society in which knowledge is a core asset to production, the ability to utilize information and produce knowledge using IT is emerging as essential to learning [1]. Since the 2000s, the philosophy of "sharing" based on Web 2.0 has been transcending "sharing” via Open Education Resources (OERs); in academic communication, the scope extends to Open Course Ware (OCW). As e-learning initially changed higher education paradigms, the expansion of open education based on "sharing" anticipates yet another paradigm shift [2].

Massive Open Online Courses (MOOCs) have recently been introduced in response to such changes and are now being considered an alternate form of open education. "MOOCs" refer to a learning model that was developed for those who desire to learn in an online environment without the limitations of class size. MOOCs are an evolved e-learning system that integrate existing forms of remote learning, connection to social networks, multi-disciplinary expert participation, and free online resource collection. This form of education is growing exponentially due to active participation in learning purpose, prerequisite learning, knowledge, and common interest [3]. MOOCs are especially popular in the contexts of reeducation and knowledge sharing in the contexts of continuing education, improvements to teaching, and university student creativity and integrated thinking through its support of high-level content and teaching [4].

Until recently, studies on Information System (IS) have evaluated the success of IS in terms of user acceptance or use. However, if IS is not used continuously after being accepted, user performance fails since continued use is an essential factor in IS success [5]. In light of this, Bhattacherjee (2001) [6] asserts that if IS user expectations are identical to use performance, perceived usefulness and use satisfaction also increase; consequently, continuation intention increases, thus fulfilling the IS Continuance Model. Later, a Continuance Model is applied to various IS study contexts and is considered to be a core model of explaining user IS continuance [7].

Additionally, current IT technologies have been developed as measures to process works by members of organizations, thus transcending personal levels. The relationship between IT technology and infra and business supports is being continuously reinforced. The Task-Technology Fit model explains IT is capacity to support an organization's members' tasks by referencing how well IT supports the functions required for an individual to perform a task [8]. Previous studies on IS demonstrate that Task-Technology Fit improves individual user performance by improving the fit between information systems and tasks conducted in the use environments' various systems [9-14].

Similarly, previous studies on MOOCs have focused on evaluating MOOCs' educational potential from the service provider's point of view despite its importance, while studies on MOOCs' acceptance or use environment from point of view of the learner are shorter $[15,16]$. Therefore, this study presents an extended research model, combining IS continuance and task-technology fit models through literature research. We reveal the factors of continuous use after the learner accepts an MOOC, and analyze the model empirically. It is important to understand the MOOCs' learners' environment: a strategic direction for successful settlement and diffusion of MOOCs is presented based on this understanding.

To this purpose, a survey was conducted on experienced users of MOOCs; the results were analyzed and our hypothesis verified using the structural equation model. Therefore, to 
achieve its purpose, this study was designed and constructed as a literature review and theoretical framework. This study was divided into five sections. Section 1 introduces the study's thesis, objectives, scope, and organization. Section 2 presents a research hypothesis based on a review of major concepts and theories. Section 3 presents the study's sample, measure, and analysis method. Section 4 presents the data analyses and findings. Section 5 presents a summary and future research directions based on the theoretical model's test results.

\section{Theoretical Background}

\subsection{Understanding MOOCs}

MOOCs are a learning model developed for those who desire to gain education in an online environment without limitations of class size. This means that free lectures are available to anyone, allowing students to participate in learning through an open, public online community [17]. MOOCs are intrinsically different from existing educational environments as they are "Massive," "Open," "Online," and in the form of "Courses" [18]. First, as opposed to existing offline or online courses, many students of MOOCs participate in learning activities. Second, MOOCs are open in terms of economy, acceptance, and sharing. MOOC lectures are offered for free, and have no preconditions for course participants; lectures are open to everyone, and hence students can share their own thoughts and understandings freely while they study. MOOCs are delivered online; therefore, courses are easily accessible and free from physical and temporal limitations. Lastly, MOOC lectures are defined as "courses." A lecture provided by MOOCs has a beginning and an end; organized learning resources and activities are provided to achieve learning goals set by the teacher.

In sum, MOOCs are online courses comprising free lecture selections, openly shared curricula, and unlimited outcomes in an open structure. MOOCs are established by autonomously organized learners who participate in lectures according to their learning purposes, previous technological knowledge level, and common interests. MOOCs do not generally charge a fee and have no preconditions save for interest and internet access. There are no previously defined expectations or formal requirements for participation in these courses. MOOCs target unlimited participation and open access through the Web. Unlike other classes, MOOCs offer interactive user forums to support the formation of user communities $[19,20]$.

As such, public interest in MOOCs is increasing since anyone can receive high quality education online with no preconditions. However, in spite of the high interest in MOOCs, a problem is emerging: many learners quit in the middle of a course. The number of participants registered in MOOCs is increasing rapidly, and most of these participants enjoy MOOC learning. However, few students complete the courses and receive certificates [21,22]. In an investigation conducted on 43,000 students using Coursera, Udacity, edX and other MOOC platforms, Jordan (2015) [23] reveals that only 6.5\% of students attended all of the lectures and received certificates or diplomas. Meyer (2012) [24] reports that the rate of exiting students from MOOCs provided by Stanford, MIT, and UC Berkley is 80-95\%. This high exit rate is considered a limitation of MOOCs despite their potential to lead innovation in education paradigms and curricula.

\subsection{Task-Technology Fit}

The Task-Technology Fit (TTF) model is used extensively to evaluate IT technology's performance challenges. Task-technology fit is defined as the level at which an information system's capacity is identical to the required conditions of tasks to perform and meaning that it 
addresses the issue of how adequately technology can support the information required for individual task performance $[25,26]$. While presenting the task-technology fit model, Goodhue \& Thompson (1995) [8] argue that task-technology fit determines the performance of utilization in the use environment of IT technology. These researchers note that if IT is sufficient to support task performance, user evaluation will be positive, and IT will be used.

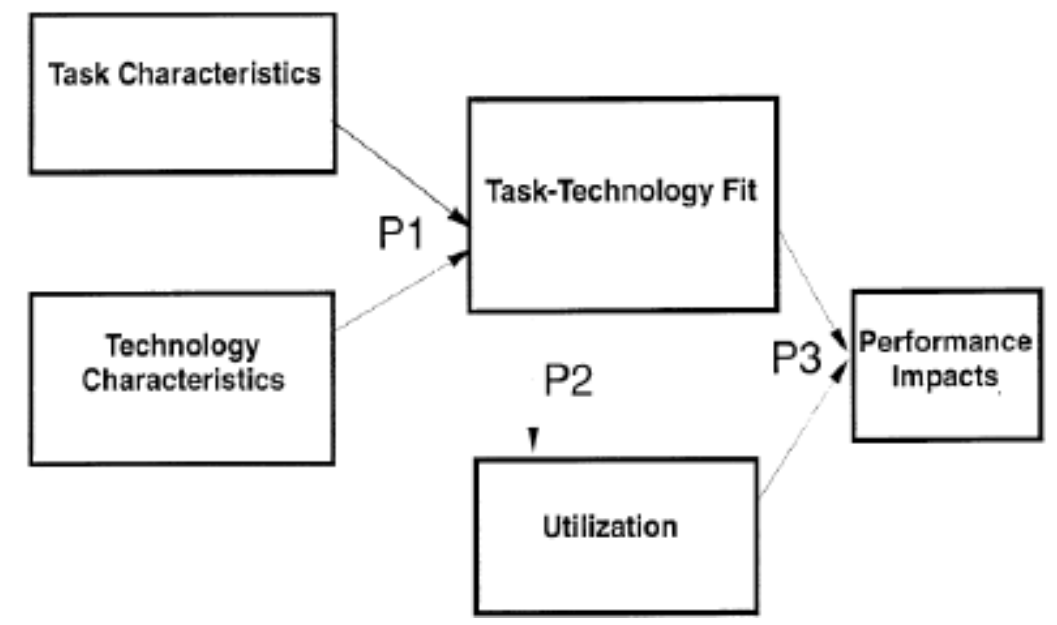

Fig. 1. The Task-Technology Fit Model

Therefore, the task-technology fit model is considered a foundational model for describing user performance in IT acceptance and use research [14,27-30]. Klopping \& McKinney's (2004) [9] study on e-commerce acceptance confirms that task-technology fit positively impacts perceived usefulness, ease of use, and intention to use. Larsen et al.'s (2009) [31] study on mobile banking continuance verifies that the task-technology fit affects perceived usefulness and utilization, while utilization and user satisfaction positively affect continuance intention. McGill \& Klobas' (2009) [10] study on Learning Management Systems (LMSs) verifies that task-technology fit and utilization impacts learning performance. Zhou et al (2010) [11] show that task-technology fit has a positive effect on mobile banking acceptance and performance expectation. Chang's (2010) study [12] on the acceptance of mobile auction service verifies that task-technology fit positively impacts intention to use by mediating perceived usefulness. Lin \& Wang's (2012) [13] study on e-learning continuation intention verifies that task-technology fit positively impacts confirmation and perceived usefulness. Therefore, this study establishes the following hypotheses:

H1. Task-Technology Fit will have a positive effect on perceived usefulness.

H2. Task-Technology Fit will have a positive effect on utilization.

H3. Utilization will have a positive effect on user satisfaction.

H4. Utilization will have a positive effect on continuance intention.

\subsection{IS Continuance}

Ultimately, if use continuation fails after IS acceptance, user achievement also fails; IS success depends on continued use rather than acceptance [6]. An IS that is not used frequently, or is inadequate or ineffective after being accepted, can become a factor in failing to achieve the performance of the individual or the organization; continued usage after acceptance is an essential factor for the success of IS in the use environment [5]. Therefore, Bhattacherjee 
(2001) [6] presents an IS continuance model based on Davis et al.'s (1989) Technology Acceptance Model (TAM) [32] and Oliver's (1980) Expectancy Disconfirmation Theory (EDT) [33] asserting that an IS' continuation intention is determined by confirmation and perceived usefulness produced by the results of initial use of IS; confirmation influences perceived usefulness. In other words, his assertion means that when IS user expectations meet use performance in the initial period, perceived usefulness and satisfaction increase and continuation intention consequentially increases.

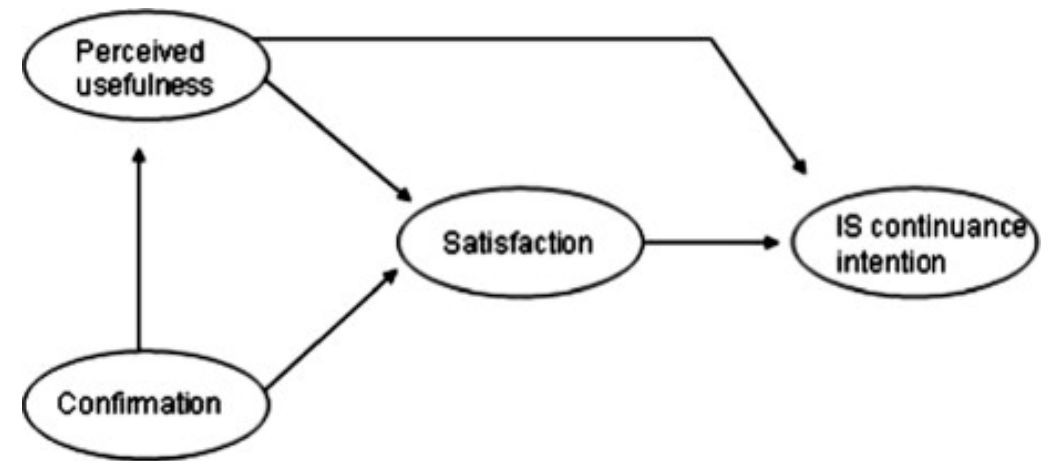

Fig. 2. IS Continuance Model

Bhattacherjee's (2001) [6] IS continuance model is considered to be a core model demonstrating user IS continuance since it applies to various contexts of later IS continuance research [7]. Hsu \& Chiu's (2004) [34] study on IS continuation intention verifies that the continuation intention of internet service is determined by outcome expectation, internet self-efficacy and user satisfaction, while confirmation is a factor in predicting outcomes of expectation and user satisfaction. Lin et al. (2005) [35] verify that the continuation intention of web portal services is determined by perceived usefulness, playfulness, and user satisfaction; expectation satisfaction is a factor in predicting perceived usefulness, perceived playfulness, user satisfaction, and expectation satisfaction. Roca et al. (2006) [36] verify that the continuation intention of e-learning users is determined by user satisfaction and perceived quality; perceived usefulness and ease of use are prediction factors for user satisfaction. Thong et al. (2006) [37] verify that the continuation intention of mobile service is determined by user satisfaction, perceived usefulness, and enjoyment; expectation is a prediction factor for perceived ease of use, perceived usefulness, perceived enjoyment, and user satisfaction. Limayem \& Cheung (2008) [38] verify that IS continuation intention, prior behaviors, and habits are determining factors of e-learning service continuation. Kim (2010) [39] verifies that perceived usefulness, enjoyment, cost, subjective norms, and perceived behavior controls are determining factors for mobile data service continuation. Ho (2010) [40] verifies that continuation of e-learning services are determined by perceived usefulness, user satisfaction, and attitude; autonomy, relatedness, competence, expectation satisfaction, and perceived ease of use are prediction factors for perceived usefulness, user satisfaction and attitude. Therefore, this study establishes the following hypotheses:

H5. Perceived usefulness will have a positive effect on utilization.

H6. Perceived usefulness will have a positive user satisfaction.

H7. Perceived usefulness will have a positive continuance intention.

H8. User satisfaction will have a positive effect on continuance intention to use. 
On the basis of the above hypotheses, the following model, shown in Fig. 3, was suggested for this study.

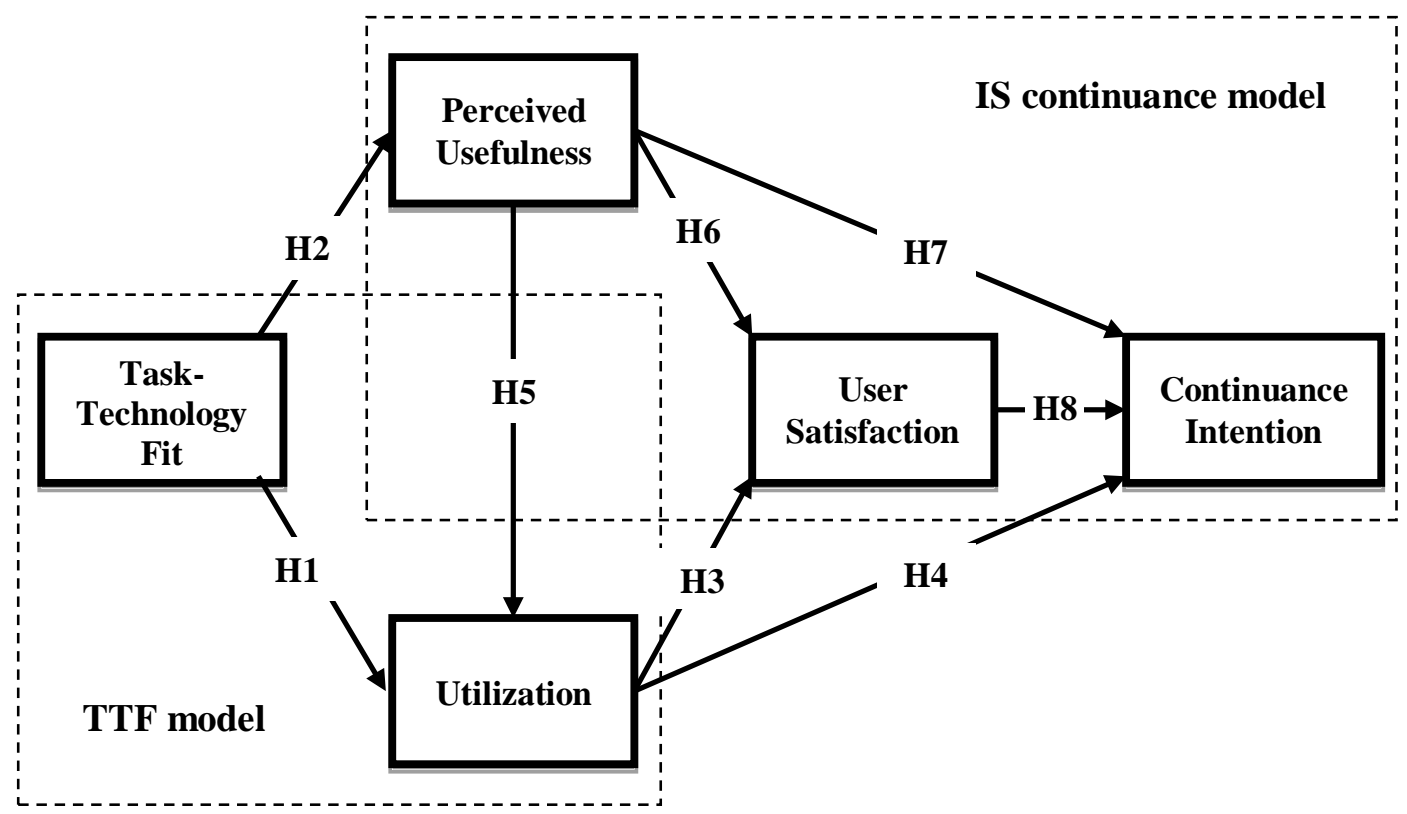

Fig. 3. Research Model

\section{Research Method}

\subsection{Sample}

For this study, data were collected through a field survey on college/university graduate students, and adult students enrolled in courses at life-long education centers located in Seoul; all of these participants have experience using MOOC services. A total of 252 data samples were collected, and 237 cases remained as effective samples for this study's empirical analysis after eliminating 15 cases that had missing values or insincere responses. Table 1 summarizes this study's samples.

Table 1. Sample Characteristics

\begin{tabular}{|c|c|c|c|}
\hline \multicolumn{2}{|c|}{ Category and Items } & Sample Size & Ratio (\%) \\
\hline \multirow{2}{*}{ Gender } & Male & 123 & 51.9 \\
\hline & Female & 114 & 48.1 \\
\hline \multirow{5}{*}{ Age } & Less than 20 & 16 & 6.8 \\
\hline & $20-29$ & 105 & 44.3 \\
\hline & $30-39$ & 58 & 24.5 \\
\hline & $40-49$ & 39 & 16.5 \\
\hline & more than 50 & 19 & 8.0 \\
\hline \multirow{5}{*}{ Use period } & Less than 6 months & 36 & 15.2 \\
\hline & 6-12 months & 47 & 19.8 \\
\hline & 12-18 months & 110 & 46.4 \\
\hline & 18-24 months & 36 & 15.2 \\
\hline & more than 24 months & 8 & 3.4 \\
\hline
\end{tabular}




\subsection{Measure}

To ensure the content validity of our measurement tool, this study used measurement items verified in existing literature by revising and supplementing them for our purposes. First, Task-Technology Fit was constructed into four items, each referencing studies of Goodhue \& Thompson (1995) [8], Larsen et al. (2009) [31], and Lin (2012) [41]; these were measured using a seven-point Likert scale (Strongly disagree Strongly agree). Utilization was also constructed into four items, each referencing studies by Goodhue \& Thompson (1995) [8], Larsen et al. (2009) [31], and Lin \& Wang(2012) [13]; these too were measured using a seven-point Likert scale. Perceived Usefulness was constructed into four items, each referencing studies by Davis (1989) [32], Bhattacherjee (2001) [6], and Lee (2010) [42]; these were measured using a seven-point Likert scale. User Satisfaction was constructed into four items, each referencing studies by Bhattacherjee (2001) [6], and Limayem \& Cheung (2008) [38]; these were measured using a seven-point Likert scale. Continuance Intention was constructed into four items, each referencing studies by Bhattacherjee (2001) [6], Limayem \& Cheung (2008) [38], and Lee (2010) [42]; these were measured using a seven-point Likert scale.

\subsection{Analysis method}

For a method of analysis and measurement tool of structural equation models, this study analyzed results and verified the hypothesis using Amos 24.0.

\section{Analysis and Results}

\subsection{Measurement Model}

This study conducted a confirmatory factor analysis to ensure the measurement tool's content validity. As a result of the modified measurement model's confirmatory factor analysis, $\chi 2=$ 394.152 $(\mathrm{P}=0.000), \chi 2 / \mathrm{df}=2.463, \mathrm{RMSEA}=.079, \mathrm{AGFI}=.810, \mathrm{CFI}=.944, \mathrm{IFI}=.944, \mathrm{TLI}$ $=.933$, indicating that measurement model was fit. Next, reliability and validity tests were conducted for measurement items. For reliability, construct reliability should appear above 0.7, and average variance extract should be above 0.5. Additionally, two latent variables' AVE1 and AVE2 should be larger than the squared value of its correlation for validity. As a result of analysis, reliability and validity were verified; the detailed results are presented in Table 2 and Table 3.

\subsection{Structural Model}

A structural model analysis was conducted to measure the model's fitness, and reliability and validity of measurement items were verified. As a result of the structural model's fitness test, $\chi 2=395.747(\mathrm{P}=.000), \chi 2 / \mathrm{df}=2.443$ was above the threshold of 3 , and RMSEA $=.078$ was below the standard of .08. Moreover, AGF $=.812$ indices appeared above the recommended value of 0.8. Also, $\mathrm{CFI}=.944, \mathrm{IFI}=.944, \mathrm{TLI}=.934$ indices were above the recommended value of 0.9 ; therefore, the research model's goodness of fit was verified.

\subsection{Hypotheses Test}

The research hypotheses were tested after the structural model's fitness was confirmed. Consequently, task-technology fit had a positive effect on utilization (C.R. $=3.361, \mathrm{p}=.000$ ) and perceived usefulness $(\mathrm{C} . \mathrm{R} .=10.898, \mathrm{p}=.000)$; therefore, $\mathrm{H} 1$ and $\mathrm{H} 2$ were supported. 
Second, utilization had a positive effect on user satisfaction (C.R. $=3.815, \mathrm{p}=.000$ ); therefore, H3 was supported. On the other hand, the utilization did not have a significant effect on the continuance intention to use (C.R. $=-1.284, \mathrm{p}=.199$ ); therefore, H4 was not supported. Third, perceived usefulness has a positive effect on utilization (C.R. $=2.191, \mathrm{p}=.028$ ), user satisfaction (C.R. = 7.854, $\mathrm{p}=.000$ ), and continuance intention to use (C.R. = 7.295, $\mathrm{p}=.000$ ); therefore, H5, H6 and H7 were supported. Lastly, user satisfaction had an effect on continuance intention to use (C.R. $=4.903, \mathrm{p}=.000)$; thus, $\mathrm{H} 8$ was supported. The results of the hypothesis tests are summarized in Table 4 and Fig. 4.

Table 2. Confirmatory Factor Analysis based on Reliability

\begin{tabular}{|c|c|c|c|c|c|c|}
\hline Variables & $\begin{array}{l}\text { Measurement } \\
\text { Item }\end{array}$ & $\begin{array}{c}\text { Std. } \\
\text { Loading }\end{array}$ & $\begin{array}{l}\text { Std. } \\
\text { Error }\end{array}$ & C. R. & $\begin{array}{l}\text { Construct } \\
\text { Reliability }\end{array}$ & $\begin{array}{c}\text { Cronbach' } \\
\text { s } \alpha\end{array}$ \\
\hline \multirow{4}{*}{$\begin{array}{c}\text { Task-Technology } \\
\text { Fit }\end{array}$} & TTF1 & .878 & & & \multirow{4}{*}{.869} & \multirow{4}{*}{.879} \\
\hline & TTF2 & .829 & .059 & 15.720 & & \\
\hline & TTF3 & .715 & .062 & 12.603 & & \\
\hline & TTF4 & .789 & .060 & 14.598 & & \\
\hline \multirow{4}{*}{ Utilization } & PU1 & .896 & & & \multirow{4}{*}{.910} & \multirow{4}{*}{.928} \\
\hline & PU2 & .871 & .051 & 19.265 & & \\
\hline & PU3 & .878 & .052 & 19.615 & & \\
\hline & PU4 & .847 & .051 & 18.166 & & \\
\hline \multirow{4}{*}{$\begin{array}{l}\text { Perceived } \\
\text { Usefulness }\end{array}$} & UT1 & .899 & & & \multirow{4}{*}{.947} & \multirow{4}{*}{.949} \\
\hline & UT2 & .921 & .042 & 22.716 & & \\
\hline & UT3 & .893 & .042 & 21.019 & & \\
\hline & UT4 & .924 & .041 & 22.890 & & \\
\hline \multirow{4}{*}{$\begin{array}{c}\text { User } \\
\text { Satisfaction }\end{array}$} & SF1 & .820 & & & \multirow{4}{*}{.935} & \multirow{4}{*}{.929} \\
\hline & SF2 & .891 & .063 & 16.927 & & \\
\hline & SF3 & .890 & .066 & 16.905 & & \\
\hline & SF4 & .904 & .064 & 17.294 & & \\
\hline \multirow{4}{*}{$\begin{array}{c}\text { Continuance } \\
\text { Intention }\end{array}$} & CI1 & .826 & & & \multirow{4}{*}{.937} & \multirow{4}{*}{.894} \\
\hline & $\mathrm{CI} 2$ & .823 & .069 & 14.600 & & \\
\hline & $\mathrm{CI} 3$ & .845 & .075 & 15.128 & & \\
\hline & CI4 & .804 & .076 & 14.124 & & \\
\hline
\end{tabular}

Table 3. Correlations between Constructs and Validity

\begin{tabular}{|c|c|c|c|c|c|}
\hline Variables & 1 & 2 & 3 & 4 & 5 \\
\hline $\begin{array}{c}\text { 1.Task- } \\
\text { Technology Fit }\end{array}$ & $.546 * *$ & & & & \\
\hline 2.Utilization & $.124^{*}$ & $.666^{* *}$ & & & \\
\hline $\begin{array}{c}\text { 3.Perceived } \\
\text { Usefulness }\end{array}$ & $.507 *$ & $.516^{*}$ & $.608 * *$ & & \\
\hline 4.User Satisfaction & $.174^{*}$ & $.347 *$ & $.436^{*}$ & $.791 * *$ & \\
\hline $\begin{array}{l}\text { 5.Continuance } \\
\text { Intention }\end{array}$ & $.536 *$ & $.349 *$ & $.582 *$ & $.421 *$ & $.758 * *$ \\
\hline
\end{tabular}

*squared value of correlation $\left(\varnothing^{2}\right)$

**AVE (Average Variance Extract) 
Table 4. Hypothesis Test Results

\begin{tabular}{|c|c|c|c|c|}
\hline \multicolumn{2}{|c|}{ Hypothesis Path } & $\begin{array}{c}\text { Estimate } \\
(\boldsymbol{\beta})\end{array}$ & $\begin{array}{c}\text { C.R. } \\
(\mathbf{t})\end{array}$ & Results \\
\hline \hline H1 & Task-Technology Fit $\rightarrow$ Utilization & .335 & $3.361^{* * *}$ & Supported \\
\hline H2 & Task-Technology Fit $\rightarrow$ Perceived Usefulness & .742 & $10.898^{* * *}$ & Supported \\
\hline H3 & Utilization $\rightarrow$ User Satisfaction & .187 & $3.815^{* * *}$ & Supported \\
\hline H4 & Utilization $\rightarrow$ Continuance intention & -.044 & -1.284 & $\begin{array}{c}\text { Not } \\
\text { Supported }\end{array}$ \\
\hline H5 & Perceived Usefulness $\rightarrow$ Utilization & .199 & $2.191^{*}$ & Supported \\
\hline H6 & Perceived Usefulness $\rightarrow$ User Satisfaction & .410 & $7.854^{* * *}$ & Supported \\
\hline H7 & Perceived Usefulness $\rightarrow$ Continuance intention & .311 & $7.295^{* * *}$ & Supported \\
\hline H8 & User Satisfaction $\rightarrow$ Continuance intention & .267 & $4.903^{* * *}$ & Supported \\
\hline
\end{tabular}

$* \mathrm{p}<0.05, * * \mathrm{p}<0.01, * * * \mathrm{p}<0.001$

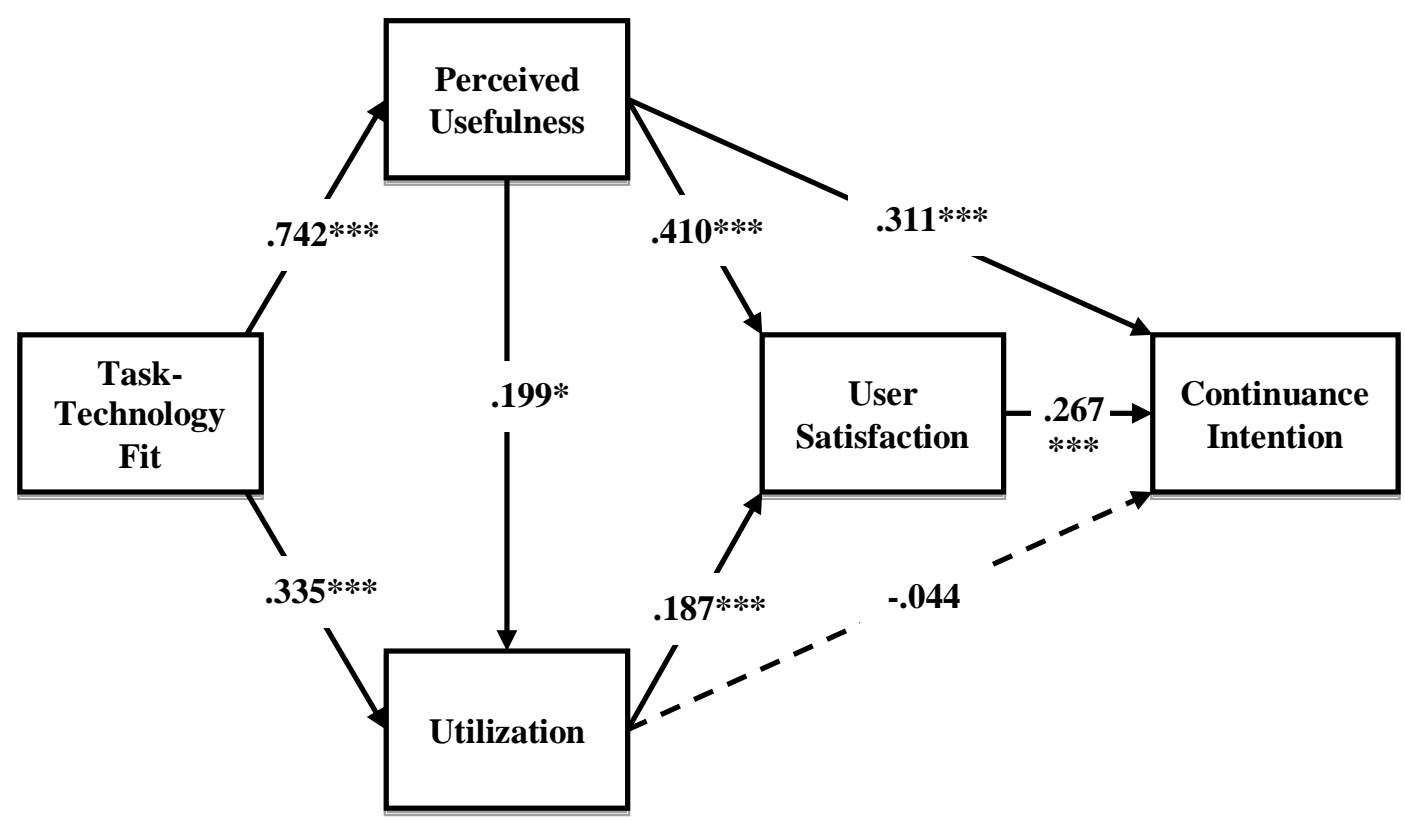

${ }^{*} \mathrm{p}<0.05, * * \mathrm{p}<0.01, * * * \mathrm{p}<0.001, \mathrm{~ns}$ : insignificant at the 0.05 level

Fig. 4. Research Model and Path Analysis 


\section{Conclusion}

In our current, information-based society in which knowledge comprises the core of production, the capability to utilize information and produce knowledge with IT is emerging as essential to learning. Accordingly, MOOCs have recently been introduced and are being recognized as an alternative to new forms of open education. Therefore, this study presents an extended research model which combines IS continuance and task-technology fit models through literature research, revealing factors of continued learner use after accepting MOOCs, and analyzes the model empirically.

In this study we found that task-technology fit has a positive effect on the utilization and perceived usefulness in MOOC use environment; additionally, the use of task-technology fit has a positive effect on intention of continued use. The task-technology fit affects the use of production performance IT when performing specific tacks utilizing IT [31]. Therefore, if the MOOCs are sufficient to support learning in the MOOCs use environment, it can be understood that the user evaluates the use of the MOOCs and uses them positively.

Additionally, it was found that perceived usefulness positively affects usability, user satisfaction, and intention of continuous use: user satisfaction has a positive effect on intention of continuous use. The more an MOOC user perceives that the MOOC's use is helpful to learning and increases the effects of learning, the more they are satisfied with an MOOC's function and output, leading to continued use [43]. If IS is not used frequently after acceptance, however, and if it is inappropriate and ineffective, IS is a failure factor in achieving good results [5]. Therefore, this study found that perceived usefulness and user satisfaction in an MOOC use environment are important predictors of an intention of continued use of MOOCs. The results of this study suggest that an MOOC's success is defined as continued use in an acceptance environment and that the MOOC's validity as a research model is verified by examining the factors that affect intention to use MOOCs. Recently, the importance of MOOCs as a means by which to enhance the quality of higher education and bolster a university's competitiveness has increased, but empirical study on the issue is insufficient $[15,16]$. Therefore, this study is academically significant since it confirms the factors affecting users' intention to use MOOCs continuously in use environments by applying task-technology fit and IS Continuance models.

Additionally, according to this study's results, it is important for the success and competitiveness of MOOCs to increase their service utilization by improving the fitness of tasks and technologies in their environments. Therefore, it is expected that the present study will have practical value as it helps us to understand MOOCs' usage environment and presents strategic directions for the successful establishment and diffusion of MOOCs.

In this study, we collected and empirically analyzed data regarding experienced adult university MOOC users in Seoul who participated in life-long education center curriculum. Ther efore, the extent to which we can generalize the results of this study is limited. In addition, to determine the factors of MOOC success, we examined previous studies on IS success, presented task-technology fit, level of use, perceived usefulness, and user satisfaction as determinants of an continuance intention, and verified them empirically. We expect that by further reviewing various MOOCs services and learner-level success factors, we will be able 
to gain a broader understanding of the success of MOOCs.

\section{References}

[1] M. J. Rosenberg, "Beyond e-learning. Approaches and Technologies to enhance Organizational Knowledge," Learning, and Performance. John Wiley \& Sons, 2005.

[2] L. Yuan and S. Powell, "MOOCs and open education: Implications for higher education," 2013. Article (CrossRef Link)

[3] J. Reich, “Rebooting MOOC research” Science, Vol 347, No. 6217, pp. 34-35, 2015. Article (CrossRef Link)

[4] C. Alario-Hoyos, M. Pérez-Sanagustín, C. Delgado-Kloos, M. Muñoz-Organero and A. Rodríguez-de-las-Heras, "Analysing the impact of built-in and external social tools in a MOOC on educational technologies," in Proc. of European Conference on Technology Enhanced Learning, pp. 5-18, 2013. Article (CrossRef Link)

[5] A. Bhattacherjee, J. Perols and C. Sanford, "Information technology continuance: A theoretic extension and empirical test,” Journal of Computer Information Systems, Vol 49, No. 1, pp. 17-26, 2008. Article (CrossRef Link)

[6] A. Bhattacherjee, "Understanding information systems continuance: an expectation-confirmation model,” MIS quarterly, Vol 25, No. 3, pp. 351-370, 2001. Article (CrossRef Link)

[7] A. Bhattacherjee and A. Barfar, "Information technology continuance research: current state and future directions," Asia Pacific Journal of Information Systems, Vol 21, No. 2, pp. 1-18, 2011.

[8] D. L. Goodhue and R. L. Thompson, "Task-technology fit and individual performance," MIS quarterly, Vol 19, No. 2, pp. 213-236, 1995. Article (CrossRef Link)

[9] I. M. Klopping and E. McKinney, "Extending the technology acceptance model and the task-technology fit model to consumer e-commerce," Information Technology, Learning, and Performance Journal, Vol 22, No. 1, pp. 35-48, 2004. Article (CrossRef Link)

[10] T. J. McGill and J. E. Klobas, "A task-technology fit view of learning management system impact," Computers \& Education, Vol 52, No. 2, pp. 496-508, 2009. Article (CrossRef Link)

[11] T. Zhou, Y. Lu and B. Wang, "Integrating TTF and UTAUT to explain mobile banking user adoption," Computers in human behavior, Vol 26, No. 4, pp. 760-767, 2010. Article (CrossRef Link)

[12] H. H. Chang, "Task-technology fit and user acceptance of online auction," International Journal of Human-Computer Studies, Vol 68, No. 1, pp. 69-89, 2010. Article (CrossRef Link)

[13] W. S. Lin and C. H. Wang, "Antecedences to continued intentions of adopting e-learning system in blended learning instruction: A contingency framework based on models of information system success and task-technology fit,” Computers \& Education, Vol 58, No.1, pp. 88-99, 2012. Article (CrossRef Link)

[14] T. Oliveira, M. Faria, M. A. Thomas and A. Popovič, "Extending the understanding of mobile banking adoption: When UTAUT meets TTF and ITM," International Journal of Information Management, Vol 34, No. 5, pp. 689-703, 2014. Article (CrossRef Link)

[15] K. S. Hone and G. R. El Said, "Exploring the factors affecting MOOC retention: A survey study," Computers \& Education, 98, 157-168, 2016. Article (CrossRef Link)

[16] L. Huang, J. Zhang and Y. Liu, "Antecedents of student MOOC revisit intention: Moderation effect of course difficulty,” International Journal of Information Management, 37(2), 84-91, 2017. Article (CrossRef Link)

[17] J. Reich, "MOOC completion and retention in the context of student intent," EDUCAUSE Review Online, 2014. Article (CrossRef Link)

[18] F. M. Hollands and D. Tirthali, "MOOCs: Expectations and Reality," Full report. Online Submission, 2014. Article (CrossRef Link)

[19] A. Chiappe-Laverde, N. Hine and J. A. Martínez-Silva, "Literatura y práctica: una revisión crítica acerca de los MOOC,” Comunicar, Vol 22, No. 44, pp.9-18, 2015. Article (CrossRef Link) 
[20] R. Saadatdoost, A. T. H. Sim, H. Jafarkarimi and J. Mei Hee, "Exploring MOOC from education and Information Systems perspectives: a short literature review,” Educational Review, Vol 67, No. 4, pp. 505-518, 2015. Article (CrossRef Link)

[21] Y. Wang and R. Baker, "Content or platform: Why do students complete MOOCs?,” Journal of Online Learning and Teaching, Vol 11, No. 1, 17-30, 2015. Article (CrossRef Link)

[22] R. F. Kizilcec, M. Pérez-Sanagustín and J. J. Maldonado, "Recommending self-regulated learning strategies does not improve performance in a MOOC," in Proc. of Proceedings of the Third (2016) ACM Conference on Learning@ Scale, ACM, pp. 101-104, 2016. Article (CrossRef Link)

[23] K. Jordan, "Massive open online course completion rates revisited: Assessment, length and attrition,” The International Review of Research in Open and Distributed Learning, Vol 16, No. 3, pp. 341-358, 2015. Article (CrossRef Link)

[24] R. Meyer, “What it’s like to teach a MOOC (and what the heck’sa MOOC?),” The Atlantic, 2012. Article (CrossRef Link)

[25] M. T. Dishaw and D. M. Strong, "Supporting software maintenance with software engineering tools: A computed task-technology fit analysis,” Journal of Systems and Software, Vol 44, No. 2, pp. 107-120, 1998. Article (CrossRef Link)

[26] R. M. Fuller and A. R. Dennis, "Does fit matter? The impact of task-technology fit and appropriation on team performance in repeated tasks," Information Systems Research, Vol 20, No. 1, pp. 2-17, 2009. Article (CrossRef Link)

[27] K. Mathieson and M. Keil, "Beyond the interface: Ease of use and task/technology fit," Information \& Management, Vol 34, No. 4, pp. 221-230, 1998. Article (CrossRef Link)

[28] P. C. Pendharkar, M. Khosrowpour and J. A. Rodger, "Development and testing of an instrument for measuring the user evaluations of information technology in health care,” Journal of Computer Information Systems, Vol 41, No. 4, pp. 84-89, 2001. Article (CrossRef Link)

[29] S. Jarupathirun and F. M. Zahedi, "Exploring the influence of perceptual factors in the success of web-based spatial DSS,” Decision Support Systems, Vol 43, No. 3, pp. 933-951, 2007. Article (CrossRef Link)

[30] T. C. Lin and C. C. Huang, "Understanding knowledge management system usage antecedents: An integration of social cognitive theory and task technology fit,” Information \& Management, Vol 45, No. 6, pp. 410-417, 2008. Article (CrossRef Link)

[31] T. J. Larsen, A. M. Sørebø and Ø. Sørebø, “The role of task-technology fit as users' motivation to continue information system use,” Computers in Human Behavior, Vol 25, No. 3, pp. 778-784, 2009. Article (CrossRef Link)

[32] F. D. Davis, R. P. Bagozzi and P. R. Warshaw, "User acceptance of computer technology: a comparison of two theoretical models,” Management science, Vol 35, No. 8, pp. 982-1003, 1989. Article (CrossRef Link)

[33] R. L. Oliver, "A cognitive model of the antecedents and consequences of satisfaction decisions," Journal of marketing research, Vol 17, No. 4, pp. 460-469, 1980. Article (CrossRef Link)

[34] M. H. Hsu, C. M. Chiu and T. L. Ju, "Determinants of continued use of the WWW: an integration of two theoretical models,” Industrial management \& data systems, Vol 104, No. 9, pp. 766-775, 2004. Article (CrossRef Link)

[35] C. S. Lin, S. Wu and R. J. Tsai, "Integrating perceived playfulness into expectation-confirmation model for web portal context,” Information \& management, Vol 42, No. 5, pp. 683-693, 2005. Article (CrossRef Link)

[36] J. C. Roca, C. M. Chiu and F. J. Martínez, "Understanding e-learning continuance intention: An extension of the Technology Acceptance Model," International Journal of human-computer studies, Vol 64, No. 8, pp. 683-696, 2006. Article (CrossRef Link)

[37] J. Y. Thong, S. J. Hong and K. Y. Tam, "The effects of post-adoption beliefs on the expectation-confirmation model for information technology continuance," International Journal of Human-Computer Studies, Vol 64, No. 9, pp. 799-810, 2006. Article (CrossRef Link)

[38] M. Limayem and C. M. Cheung, "Understanding information systems continuance: The case of Internet-based learning technologies,” Information \& management, Vol 45, No. 4, pp. 227-232, 2008. Article (CrossRef Link) 
[39] B. Kim, "An empirical investigation of mobile data service continuance: Incorporating the theory of planned behavior into the expectation-confirmation model," Expert systems with applications, Vol 37, No. 10, pp. 7033-7039, 2010. Article (CrossRef Link)

[40] C. H. Ho, "Continuance intention of e-learning platform: Toward an integrated model," International Journal of Electronic Business Management, Vol 8, No. 3, pp. 206-215, 2010. Article (CrossRef Link)

[41] W. S. Lin, "Perceived fit and satisfaction on web learning performance: IS continuance intention and task-technology fit perspectives,” International Journal of Human-Computer Studies, Vol 70, No. 7, pp. 498-507, 2012. Article (CrossRef Link)

[42] M. C. Lee, "Explaining and predicting users' continuance intention toward e-learning: An extension of the expectation-confirmation model," Computers \& Education, Vol. 54, No. 2, pp. 506-516, 2010. Article (CrossRef Link)

[43] S. Petter, W. DeLone and E. R. McLean, "Information systems success: The quest for the independent variables," Journal of Management Information Systems, Vol. 29, No. 4, pp.7-62, 2013. Article (CrossRef Link)

Appendix. Measurement items.

\section{Task-Technology Fit}

1. It is appropriate to use MOOCs when learning.

2. MOOCs features are sufficient to complete my study.

3. MOOCs fulfill my learning objective.

4. MOOCs fit well with my learning method.

\section{Utilization}

1. I frequently use MOOCs.

2. I apply MOOCs in my study.

3. I use MOOCs learning courses.

4. I utilize MOOCs study materials.

\section{Perceived Usefulness}

1. I find MOOCs useful.

2. MOOCs assist me in acquiring information.

3. MOOCs are helpful to my learning.

4. Education quality increases when I use MOOCs.

\section{User Satisfaction}

1. I am satisfied with using MOOCs.

2. I am satisfied with MOOCs' utilities.

3. I am generally satisfied with my experience using MOOCs.

4. Utilizing MOOCs is a wise choice.

\section{Continuance Intention}

1. I plan to use MOOCs frequently in the future.

2. I plan to use MOOCs very often in the future.

3. I believe the use of MOOCs will increase.

4. I would recommend the use of MOOCs to others. 


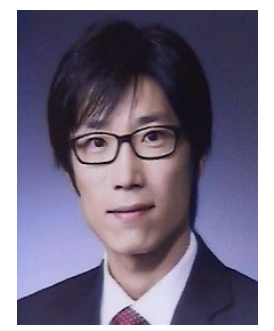

Donghyuk Jo (joe@ssu.ac.kr) is currently a professor of School of Business Administration, Soongsil University, Seoul, Korea. He received his Ph.D. in Business Administration from Soongsil University in 2013. His current research interests include Operation Management, Management Science, Technology Management and etc. 